\title{
Application of Arbuscular Mycorrhizal Fungi and Soil Ameliorant on the Growth of Leucaena leucocephala in Limestone Post-mining Soil Media
}

\author{
Siti Hanna Ghaida, Basuki Wasis, Sri Wilarso Budi" \\ Department of Silviculture, Faculty of Forestry and Environment, IPB University, Academic Ring Road, Campus IPB \\ Dramaga, Bogor, Indonesia 16680
}

Received June 23, 2020/Accepted November 18, 2020

\begin{abstract}
Limestone mining has the potential into environmental damage that involve modify an ecosystem. The attempt that contrived to reduce the disturbances are rehabilitation. This research was conducted to examine the growth response of Leucaena leucocephala inoculated with AMF and soil ameliorant in a limestone post-mining soil. The design used was a split-plot design in a completely randomized design with 3 factors. The first factor was AMF inoculum (Daemonorops draco AMF and MycoSilvi), the second factor was organic fertilizer of compost, and the third factor was inorganic fertilizer. The variables used in this study expressed by height, diameter, biomass, root colonization, and nutrient absorption of the plant. The analysis showed that the combination of MycoSilvi and compost 7.5\% gave best result of height, diameter, and biomass, with significantly increased by $962.67 \%, 899.41 \%$ and $1440.67 \%$ to control plant. It also gave best result of nutrient uptake $N, P$, and $K$, with significantly increased up to $17.64 \mathrm{~g}$ plant ${ }^{-1}$, $2.42 \mathrm{~g} \mathrm{plant}^{-1}$, and $18.05 \mathrm{~g} \mathrm{plant}^{-1}$. In general, AMF showed a good percentage of root colonization with an average $36.67-86.67 \%$. Further research is needed to determine the response to the growth of seedlings planted in the field.
\end{abstract}

Keywords: AMF, compost, MycoSilvi, limestone post-mining, Leucaena leucocephala

*Correspondence author,email: wilarso62@yahoo.com,tel: +62-251-8626806

\section{Introduction}

Indonesia has an adequate wide karst area and it has been recorded 15.4 million ha (Cahyadi, 2010; Rahmadi, 2017). Gunung kapur or limestone mountain in Ciampea, Bogor, West Java, is one of the karst regions in Indonesia with a diversity of ecosystems that play a role in maintaining hydrological functions (Wasis et al., 2019). The increase in the human population causes the utilization of karst areas to also increase, especially on the eastern part of the mountain (Afra et al., 2008).

Mining is an activity accomplish by forest clearing, stripping the soil, dredging, and landfill (Cakyayanti \& Setiadi, 2014). The block of limestone from mining results are used by communities to produce lime and raw material for making cement (Aziz, 2010; Prayudyaningsih \& Sari, 2016). On other hand, limestone mining can increase income, however, threaten environmental damage, especially underground water sources because mining can immediately damage the forest's hydrological system (Hakim, 2011), and damage to post-mining areas such as topsoil loss, decreased organic matter, low nutrient availability, high $\mathrm{pH}$, low microbial population, and damage to soil structure and texture (Prayudyaningsih et al., 2015; Aprillia et al., 2019).

Karsh ecosystem transformation effect adversity for plants to adapt (Chairul et al., 2019), tree planting activities often fail because post-mining soil conditions are not conducive to supporting its growth. Soil improvement is needed to restore ecosystems (Chen et al., 2011). Various post-mining soil treatments have been accomplished, such as by apply soil ameliorant material or by utilizing microorganisms (Prayudaningsih \& Sari 2016). Inoculation of arbuscular mycorrhizal fungi (AMF) and soil ameliorant has the potential to increase soil quality as a result of increased nutrient availability and help plants survive in marginal environmental conditions (Prayudyaningsih \& Sari, 2016). AMF is a group of fungi that has a mutual symbiosis (mutual benefit) with plant roots (Smith \& Read 2008). The ability of AMF in increasing plant growth can be combined with other microorganisms. MycoSilvi is an AMF inoculum enriched with Mycorrhizal Helper Bacteria (MHBs) which capable to increase the number of AMF spores and mycorrhizal colonization of some legume plants in silica sand post-mining soils (Jayani et al., 2018, Budi et al., 2020).

However, there is no data on the use of MycoSilvi on limestone post-mining soil. Soil ameliorant in the form of compost is useful in improving soil properties that were originally solid to lose, increase the availability of nutrients in the soil, and make microorganisms in the soil becomes developed (Setyorini et al., 2006). Urea fertilizer is useful in accelerating plant growth and photosynthesis (Pramitasari et al., 2016). In L. Leucocephala seedlings, AMF plays an 
important role in the early growth of L. leucocephala seedlings (Brandon et al., 1997). It helps in increasing plant biomass, $\mathrm{P}$ concentration, root colonization, avoiding drought stress (Dixon, 1993; Habte \& Antal, 2010). Rani et al., (2019) also stated that a mixture of soil, vermicompost, and AMF can provide optimal L. Leucocephala seedling growth in the nursery. Research Puthur et al., (1998) stated that in tissue culture, L. Leucocephala plantlets that were inoculated with AMF had better adaptability than without AMF.

L. leucocephala is a pioneer plant from Central America which is currently widely grown and spread in tropical regions such as Indonesia (Wolfe \& Van Bloem 2012; Hendrati \& Hidayati, 2018). This species is a type of fastgrowing legume which plays an important role in restoring soil fertility, prevent erosion, form root nodules, symbiosis with fungi, and to adapt in marginal land (Atawodi et al., 2008; Mansur 2013; Dharmaputri et al., 2016). Therefore, $L$. leucocephala has the potential to improve the limestone postmining soil. The purpose of this study was (1) examine the role of AMF and soil ameliorant and their interactions in increasing L. leucocephala seedlings growth in limestone post-mining soil (2) determine the most optimal treatment to increase the growth of L. leucocephala seeds in limestone post-mining soil.

\section{Methods}

Time and location of research This research was conducted in April-December 2019. The research location was carried out at the Greenhouse and Mycorrhizal Laboratory, Departement of Silviculture, Faculty of Forestry, IPB University.

Preparation for planting media and the addition of soil ameliorant Soil media (limestone mining soil) was collected from limestone mining in Ciampea, Bogor, West Java. Soil was wrapped in heat-resistant plastic and then sterilized using an autoclave at $121 \mathrm{C}$ for 1 hour (Jayani et al., 2018). The media then weighed $650 \mathrm{~g}$ polybag $^{-1}$. The sterilized soil was then added with soil ameliorant in the form of compost $(0 \%, 2.5 \%, 5 \%, 7.5 \%$, and $10 \%)$ polybag $^{-1}$ and $0.5 \mathrm{~g} \mathrm{polybag}^{-1}$ urea fertilizer. The soil was then watered and incubated for 2 weeks (Yulnafatmawita et al., 2005). Incubation serves to perfect the decomposition process and helps microorganisms develop and metabolize to break down organic matter into organic compounds (Siregar et al., 2017).

Sterilization, breaking dormancy, and sowing seeds $L$. Leucocephala seeds were originally from the collection of Silviculture Laboratory, Faculty of Forestry, IPB University. L. leucocephala seeds have a germination percentage $68-100 \%$ (Suita, 2019). Seed sterilization refers to Nusantara et al., (2012) that was the seeds are sterilized with a solution of $\mathrm{NaClO}(5.2 \%)$ for 5 minutes. The seeds are then cleaned until the odour of the solution disappears. Breaking of seed dormancy refers to Mansur (2013) that was the seeds were soaked in hot water for 3 minutes, the seeds were then soaked in cold water for 24 hours. The seeds were then drained and sown on zeolite media. Sowing was done in the afternoon to avoid excessive evaporation.
Weaning and inoculation of AMF Weaning was done after 10 days of germination. The seeds were then transferred to the planting media that has been prepared previously. $D$. draco indigeneous AMF originally from rhizosphere of $D$. draco in Sarolangun, Jambi and MycoSilvi were taken from the Greenhouse collection of the Faculty of Forestry, IPB University. Seedlings treated with AMF were inoculated with $10 \mathrm{~g}$ zeolite polybag $^{-1}$ ( $\pm 50 \mathrm{AMF}$ spores) of indigenous D. draco contains Glomus sp. + Acaulospora sp. + Scutelosphora sp. and Gigaspora sp. (Purwanti et al., 2019) and MycoSilvi consist of AMF Glomus mosseae + Acaulospora sp. and Gigaspora margarita (Budi et al., 2020) in the planting hole around the plant roots.

Maintenance and harvesting Seedlings were grown for 14 weeks in the greenhouse conditions (daily light intensity) and watered every day manually as needed to maintain holding capacity planting media. Maintenance was done by watering plants in the morning and evening following the conditions of the growing media. Harvesting was done in the last week of observation by separating plants and planting media.

Observation parameters Measurement of height $(\mathrm{cm})$ and diameter $(\mathrm{mm})$ of seedlings was carried out after weaning. Observations are carried out every two weeks. Plant biomass was measured after the seedlings are harvested and dried in an oven at $80 \mathrm{C}$ for 24 hours (Wasis \& Sa'idah, 2019). Seedlings biomass is then weighed. Observation of root colonization refers to the method of Clapp et al. (1996) that was immersed in a $20 \% \mathrm{KOH}$ solution for 48 hours, then the roots were soaked in $0.1 \mathrm{M} \mathrm{HCl}$ solution, then soaked in trypan blue dye solution for 48 hours, then the roots were soaked in a destaining solution for 24 hours.

Nutrient uptake analysis Measurement of nutrient content in seedlings was conducted at the Laboratory of the Department of Soil and Land Resources at the Faculty of Agriculture, IPB University. The nutrient uptake is calculated by multiplying the biomass and percent of plant nutrients (Ardakani et al., 2011).

Experimental design The design used in this experiment is a randomized split plot design in a completely randomized design (CRD) with 3 factors. The first factor was AMF inoculum (M) which consists of 3 levels, namely $\mathrm{M} 0=$ without inoculum AMF, M1 = AMF indigenous $D$. draco consist of Glomus sp. + Acaulospora sp. Scutelosphora sp and Gigaspora sp. (Purwanti et al., 2019), M2 = MycoSilvi contains Glomus mosseae + Acaulospora sp. and Gigaspora margarita (Budi et al., 2020). The second factor was compost (K) consisting of 5 levels namely $\mathrm{K} 0=0 \%, \mathrm{~K} 1=2.5 \%, \mathrm{~K} 2=$ $5 \%, \mathrm{~K} 3=7.5 \%$, and $\mathrm{K} 4=10 \%$. The third factor was urea fertilizer consisting of 2 levels, namely N0 $=0 \mathrm{~g}$ and $\mathrm{N} 1=0.5$ g. The total treatments tested were 30 treatments with each treatment consisting of 5 replications.

Data analysis The data that has been obtained is processed using Microsoft Excel software. The effect of the treatment on the observed variables was carried out using analysis of 
variance (ANOVA) at the $\alpha$ level of $5 \%$, followed by Duncan's multiple range test if the data show significantly different effects using SAS 9.1 software. Test the correlation between variables measured using SPSS 18 software.

\section{Results and Discussion}

Effect of AMF and soil ameliorant on the colonization of L. leucocephala seedlings roots The addition of indigenous D. draco AMF and MycoSilvi, in general, showed a percentage of root colonization in L. leucocephala seedlings. In general, control seedlings adapted well in post limestone mining soil and has survival rate $100 \%$, but the indicated growth rates were relatively slower than those treated with AMF and soil ameliorant. Seedlings treated with compost and AMF helped in the formation of plant root nodules, although rhizobium was not researched in this study, the number of seed nodules treated with AMF and soil ameliorant tended to be more than the control plants. Puthur et al., (1998) stated that AMF can increase the number of root nodules of L. leucocephala plantlets and produce stronger roots when compared to control plants.

Seedlings treated with AMF (with or without soil ameliorant) showed a high percentage of root colonization with an average of $36.67-86.67 \%$, while seedlings without AMF did not show the percentage of root colonization (control plants and plants with soil ameliorant) (Table 1). This shows that the addition of AMF has a positive effect on the percentage of $L$. leucocephala seedlings root colonization compared without AMF. Mycorrhizal association is indicated by the presence of hyphae, arbuscules, and vesicles that form in plant roots (Puthur et al., 1998). The symbiosis between AMF and plant roots can increase nutrient uptake especially in limestone post-mining soils with a dominant clay texture. (Prayudyaningsih \& Sari,
2016). AMF can produce phosphatase enzymes that convert P-bound compounds of $\mathrm{Ca}$ into ions and form external hyphae so that it is easier to enter smaller pore spaces and help absorb P nutrients further in the soil (Widiastuti et al., 2003; Manaroinsong \& Lolong, 2015; Rosita et al., 2017). It also can maintains higher leaf water potential during periods of peak water stress (Dixon et al., 1993). Mycorrhizae are able to improve physical properties that are by increasing the soil pore which helps in root penetration and respiration in limestone post-mining soil that tends to be dense (Aprillia et al., 2019). Other studies also mention that AMF can increase the percentage of root colonization in F. moluccana seeds by $90.00 \%$, S. saman by $86.67 \%, C$. siamea by $73.33 \%$, Theobroma cacao by $73.9 \%$, and Tectona grandis by $74.97 \%$ (Rahmayanti et al., 2013; Prayudyanignsih \& Sari 2016; Jayani et al., 2018).

Effect of AMF and soil ameliorant on height, diameter, and biomass of $\mathbf{L}$. leucocephala seedlings The addition of AMF and soil ameliorant plays an important role in repairing soil damage due to mining and can support plant growth (Mansur, 2013). Post-mining soils collected in this study included sandy clay loam with low nutrient composition ( $0.54 \%$ C-organic, $0.06 \% \mathrm{~N}$, and $7.81 \mathrm{ppm} \mathrm{P}$-available). The results showed that the addition of $\mathrm{AMF}$ and soil ameliorant had a significant influence on the growth of $L$. leucocephala seedlings planted in limestone post-mining soils (Table 2). The interaction of compost $7.5 \%$ and MycoSilvi capable to provide a more optimal growth response to L. leucocephala seedlings when compared to controls. The average height, diameter, and biomass of the control seedlings only reached $7.23 \mathrm{~cm}, 0.57 \mathrm{~mm}$, and $0.50 \mathrm{~g}$, in contrast to the addition of $7.5 \%$ compost and MycoSilvi is able to produce the best average height, diameter, and biomass increase of $76.87 \mathrm{~cm}$, $5.66 \mathrm{~mm}$, and $7.70 \mathrm{~g}$ with a percent increase of $962.67 \%$,

Table 1 Mean and DMRT effects of AMF and soil ameliorant on the colonization of L. leucocephala seedlings

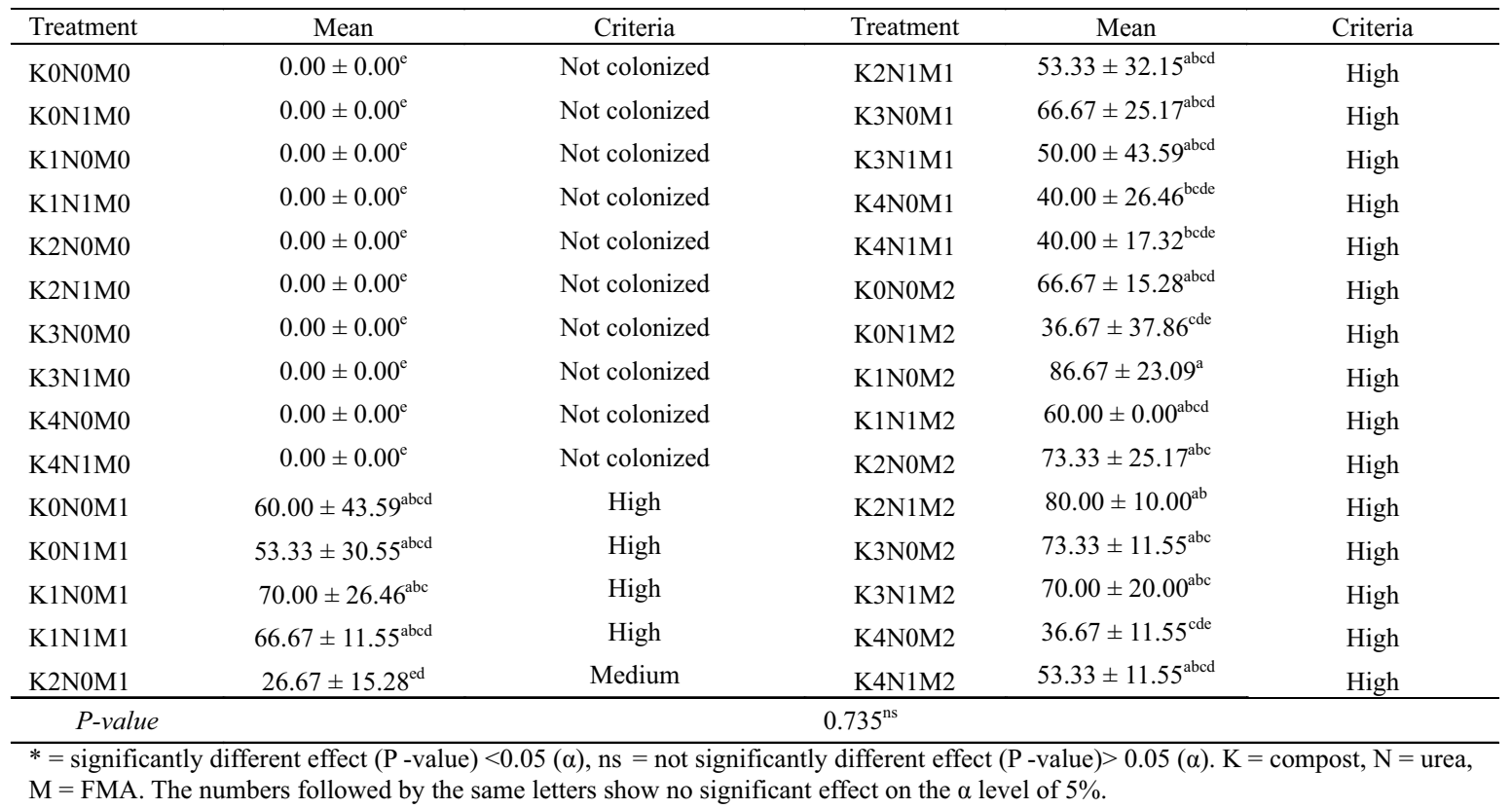


Table 2 Mean and DMRT effects of AMF and soil ameliorant on height, diameter, biomass, and nutrient uptake of L. leucocephal seedlings

\begin{tabular}{|c|c|c|c|c|c|c|}
\hline \multirow{2}{*}{ Treatment } & \multirow{2}{*}{ Height (cm) } & \multirow{2}{*}{ Diameter (mm) } & \multirow{2}{*}{ Biomass (gr) } & \multicolumn{3}{|c|}{ Nutrient uptake $\left(\mathrm{g} \mathrm{plant}^{-1}\right)$} \\
\hline & & & & $\mathrm{N}$ & $P$ & $\mathrm{~K}$ \\
\hline K0N0M0 & $7.23 \pm 0.50^{\mathrm{k}}$ & $0.57 \pm 0.23^{\mathrm{h}}$ & $0.50 \pm 0.18^{\mathrm{h}}$ & $0.82 \pm 0.25^{\mathrm{h}}$ & $0.14 \pm 0.04^{\mathrm{j}}$ & $0.49 \pm 0.15^{\mathrm{i}}$ \\
\hline K0N0M1 & $19.00 \pm 16.47^{\mathrm{ijk}}$ & $2.76 \pm 0.99^{\mathrm{fg}}$ & $0.54 \pm 0.08^{\mathrm{h}}$ & $1.04 \pm 0.09^{\mathrm{h}}$ & $0.18 \pm 0.02^{\mathrm{j}}$ & $0.62 \pm 0.13^{\mathrm{i}}$ \\
\hline K0N0M2 & $28.23 \pm 5.47^{\mathrm{hij}}$ & $3.77 \pm 0.49^{\text {cdef }}$ & $4.10 \pm 0.70^{\text {bdef }}$ & $7.15 \pm 2.41^{\mathrm{def}}$ & $1.04 \pm 0.38^{\text {efgh }}$ & $5.53 \pm 2.52^{\mathrm{fg}}$ \\
\hline K0N1M0 & $15.67 \pm 3.2^{1 \mathrm{jk}}$ & $2.41 \pm 1.01^{\mathrm{g}}$ & $1.10 \pm 0.74^{\mathrm{g}}$ & $2.34 \pm 1.75^{\mathrm{g}}$ & $0.28 \pm 0.17^{\mathrm{ij}}$ & $1.53 \pm 1.26^{\mathrm{h}}$ \\
\hline K0N1M1 & $28.43 \pm 7.59^{\text {hij }}$ & $2.26 \pm 0.50^{\mathrm{g}}$ & $1.15 \pm 0.51^{\mathrm{g}}$ & $2.19 \pm 0.9^{g}$ & $0.39 \pm 0.09^{\mathrm{hij}}$ & $1.49 \pm 0.41^{\mathrm{h}}$ \\
\hline K0N1M2 & $49.97 \pm 5.95^{\mathrm{efg}}$ & $3.68 \pm 0.16^{\mathrm{ef}}$ & $3.28 \pm 0.15^{\text {cdef }}$ & $5.96 \pm 0.38^{\mathrm{ef}}$ & $0.72 \pm 0.08^{\text {ghij }}$ & $3.24 \pm 0.15^{\mathrm{g}}$ \\
\hline K1N0M0 & $60.53 \pm 7.64^{\mathrm{abcde}}$ & $4.51 \pm 0.60^{\mathrm{abcde}}$ & $3.93 \pm 1.4^{\text {bcdef }}$ & $8.75 \pm 1.30^{\mathrm{abcd}}$ & $1.13 \pm 0.27^{\mathrm{abcdef}}$ & $6.95 \pm 3.20^{\text {abcdef }}$ \\
\hline K1N0M1 & $59.4 \pm 9.32^{\mathrm{abcde}}$ & $3.74 \pm 0.11^{\text {def }}$ & $6.15 \pm 0.96^{\mathrm{abc}}$ & $16.01 \pm 3.31^{\mathrm{ab}}$ & $1.88 \pm 0.53^{\mathrm{abcd}}$ & $12.15 \pm 2.34^{\mathrm{abcde}}$ \\
\hline K1N0M2 & $72.33 \pm 8.81^{\mathrm{abc}}$ & $5.03 \pm 0.65^{\text {abcd }}$ & $5.86 \pm 3.85^{\text {abcdef }}$ & $13.04 \pm 8.07^{\text {abcdef }}$ & $1.56 \pm 1.01^{\mathrm{bcdef}}$ & $9.58 \pm 5.98^{\text {bcdef }}$ \\
\hline K1N1M0 & $53.43 \pm 2.64^{\operatorname{defg}}$ & $3.75 \pm 0.15^{\mathrm{def}}$ & $2.64 \pm 0.59^{\mathrm{ef}}$ & $5.97 \pm 2.23^{\mathrm{f}}$ & $0.76 \pm 0.36^{\text {ghij }}$ & $6.84 \pm 2.73^{\text {def }}$ \\
\hline K1N1M1 & $33.93 \pm 5.87^{\mathrm{hi}}$ & $3.63 \pm 0.68^{\text {ef }}$ & $2.55 \pm 1.06^{\mathrm{f}}$ & $5.89 \pm 2.42^{\mathrm{f}}$ & $0.77 \pm 0.21^{\text {ghij }}$ & $6.53 \pm 2.15^{\text {ef }}$ \\
\hline K1N1M2 & $59.9 \pm 9.69^{\text {abcde }}$ & $4.10 \pm 0.44^{\mathrm{bcde}}$ & $4.04 \pm 1.18^{\text {bcdef }}$ & $9.17 \pm 1.65^{\text {abcdef }}$ & $1.30 \pm 0.33^{\text {defgh }}$ & $8.05 \pm 2.12^{\text {bcdef }}$ \\
\hline K2N0M0 & $66.53 \pm 4.46^{\mathrm{abcde}}$ & $4.15 \pm 0.25^{\mathrm{bcde}}$ & $4.77 \pm 0.69^{\mathrm{abcde}}$ & $9.42 \pm 1.66^{\text {abcdef }}$ & $1.17 \pm 0.12^{\operatorname{defgh}}$ & $10.93 \pm 2.19^{\text {abcde }}$ \\
\hline K2N0M1 & $41.5 \pm 13.48^{\mathrm{fgh}}$ & $3.84 \pm 0.26^{\text {bcdef }}$ & $4.29 \pm 0.77^{\text {abcdef }}$ & $9.88 \pm 1.68^{\text {abcdef }}$ & $1.16 \pm 0.13^{\text {defgh }}$ & $10.67 \pm 0.67^{\text {abcde }}$ \\
\hline K2N0M2 & $55.7 \pm 14.80^{\text {cdefg }}$ & $5.07 \pm 0.63^{\mathrm{abc}}$ & $7.22 \pm 1.08^{\mathrm{ab}}$ & $16.04 \pm 2.26^{\mathrm{ab}}$ & $2.31 \pm 0.57^{\mathrm{ab}}$ & $13.56 \pm 1.55^{\mathrm{ab}}$ \\
\hline K2N1M0 & $39.83 \pm 15.37^{\mathrm{gh}}$ & $4.69 \pm 0.37^{\text {abcde }}$ & $5.74 \pm 0.17^{\mathrm{abcd}}$ & $13.48 \pm 0.43^{\mathrm{abcd}}$ & $1.74 \pm 0.27^{\text {abcdef }}$ & $12.33 \pm 0.45^{\text {abcde }}$ \\
\hline K2N1M1 & $63.7 \pm 4.46^{\text {abcde }}$ & $3.95 \pm 1.47^{\text {bcdef }}$ & $2.59 \pm 0.72^{\mathrm{ef}}$ & $5.93 \pm 1.57^{\mathrm{f}}$ & $0.68 \pm 0.28^{\text {ghij }}$ & $6.81 \pm 1.31^{\text {cdef }}$ \\
\hline K2N1M2 & $72.4 \pm 2.12^{\mathrm{abc}}$ & $5.01 \pm 0.62^{\mathrm{abcd}}$ & $6.06 \pm 1.47^{\mathrm{abcd}}$ & $14.13 \pm 2.35^{\mathrm{abc}}$ & $1.88 \pm 0.46^{\mathrm{abcd}}$ & $12.74 \pm 3.28^{\text {abcde }}$ \\
\hline K3N0M0 & $59.87 \pm 4.98^{\mathrm{abcde}}$ & $4.58 \pm 0.63^{\text {abcde }}$ & $4.64 \pm 1.67^{\mathrm{zabdef}}$ & $10.85 \pm 3.34^{\text {abcdef }}$ & $1.35 \pm 0.26^{\text {cdef }}$ & $10.07 \pm 2.68^{\text {abcdef }}$ \\
\hline K3N0M1 & $56.87 \pm 13.29^{\text {bcdef }}$ & $4.25 \pm 0.46^{\text {bcde }}$ & $5.35 \pm 0.60^{\mathrm{abcd}}$ & $13.22 \pm 3.86^{\mathrm{abcd}}$ & $1.72 \pm 0.37^{\text {abcdef }}$ & $14.52 \pm 1.95^{\mathrm{ab}}$ \\
\hline K3N0M2 & $76.87 \pm 2.44^{\mathrm{a}}$ & $5.66 \pm 0.35^{\mathrm{a}}$ & $7.70 \pm 0.27^{\mathrm{a}}$ & $17.64 \pm 2.04^{\mathrm{a}}$ & $2.42 \pm 0.30^{\mathrm{a}}$ & $18.05 \pm 3.88^{\mathrm{a}}$ \\
\hline K3N1M0 & $64.83 \pm 17.17^{\text {abcde }}$ & $3.86 \pm 0.44^{\text {bcdef }}$ & $5.28 \pm 1.28^{\mathrm{abcd}}$ & $13.44 \pm 2.77^{\mathrm{abcd}}$ & $1.61 \pm 0.43^{\text {bcdef }}$ & $12.68 \pm 1.27^{\mathrm{abcd}}$ \\
\hline K3N1M1 & $68.73 \pm 8.92^{\mathrm{abcd}}$ & $4.13 \pm 0.90^{\mathrm{bcde}}$ & $6.52 \pm 0.48^{\mathrm{ab}}$ & $13.13 \pm 1.11^{\mathrm{abcd}}$ & $1.8 \pm 0.15^{\text {abcde }}$ & $15.09 \pm 1.65^{\mathrm{ab}}$ \\
\hline K3N1M2 & $73.9 \pm 7.02^{\mathrm{ab}}$ & $4.10 \pm 1.19^{\text {bcde }}$ & $6.24 \pm 1.10^{\mathrm{abc}}$ & $13.06 \pm 4.37^{\mathrm{abcd}}$ & $1.86 \pm 0.27^{\mathrm{abcd}}$ & $11.6 \pm 2.54^{\mathrm{abcde}}$ \\
\hline K4N0M0 & $61.03 \pm 0.85^{\text {abcde }}$ & $3.97 \pm 0.73^{\text {bcdef }}$ & $3.99 \pm 1.46^{\text {bcdef }}$ & $8.89 \pm 3.24^{\text {cdef }}$ & $1.14 \pm 0.5^{\text {defgh }}$ & $10.41 \pm 5.69^{\text {abcdef }}$ \\
\hline K4N0M1 & $69.83 \pm 1.59^{\mathrm{abcd}}$ & $5.11 \pm 0.68^{\mathrm{ab}}$ & $6.29 \pm 1.10^{\mathrm{abc}}$ & $14.08 \pm 1.48^{\mathrm{abc}}$ & $1.72 \pm 0.20^{\mathrm{abcdef}}$ & $13.21 \pm 1.75^{\mathrm{abc}}$ \\
\hline K4N0M2 & $64.07 \pm 14.39^{\text {abcde }}$ & $4.47 \pm 0.85^{\text {abcde }}$ & $6.21 \pm 0.52^{\mathrm{abc}}$ & $11.25 \pm 1.22^{\mathrm{abcde}}$ & $1.98 \pm 0.05^{\mathrm{abc}}$ & $12.2 \pm 1.21^{\mathrm{abcde}}$ \\
\hline K4N1M0 & $61.87 \pm 4.67^{\mathrm{abcde}}$ & $3.84 \pm 0.65^{\text {bcdef }}$ & $4.02 \pm 1.16^{\text {bcdef }}$ & $8.99 \pm 2.32^{\text {bcdef }}$ & $1.30 \pm 0.45^{\text {cdef }}$ & $9.24 \pm 1.81^{\text {abcdef }}$ \\
\hline K4N1M1 & $63.43 \pm 13.43^{\text {abcde }}$ & $3.8 \pm 0.32^{\text {bddef }}$ & $3.26 \pm 0.91^{\mathrm{def}}$ & $7.39 \pm 1.6^{\text {cdef }}$ & $0.96 \pm 0.35^{\text {fghi }}$ & $8.49 \pm 3.33^{\text {bcdef }}$ \\
\hline K4N1M2 & $69.47 \pm 13.71^{\mathrm{abcd}}$ & $4.81 \pm 0.66^{\mathrm{abcde}}$ & $7.39 \pm 2.18^{\mathrm{ab}}$ & $13.03 \pm 1.58^{\mathrm{abcd}}$ & $2.42 \pm 0.90^{\mathrm{a}}$ & $14.01 \pm 4.28^{\mathrm{ab}}$ \\
\hline$P$-value & $0.0008^{* *}$ & $0.044^{*}$ & $0.044^{*}$ & $0.029^{*}$ & $0.011^{*}$ & $0.019^{*}$ \\
\hline
\end{tabular}

$899.41 \%$ and $1,440.67 \%$ of the control. This is by research Prayudyaningsih and Sari (2016) that in the limestone postmining soil that added compost and FMA can increase the height, diameter, and biomass of $T$. grandis seedlings compared without compost and FMA. Compost can improve the physical and chemical properties of the soil (Surya et al., 2017), physical properties such as good porosity making it easier for roots to penetrate the soil (Aminah et al., 2003), chemical properties in the form of the supply of macronutrients used by plants, especially nitrogen which is a compiler of amino acids, proteins and cell protoplasms that function in stimulating vegetative growth of plants (Djamhari, 2010; Putri et al., 2016). AMF is very effective in helping vegetative growth of plants because it helps the roots absorb plant nutrients which are indicated by the increase in biomass produced (Cavagnaro et al., 2003; Ginting et al., 2018b). Some research also shows that seedlings growth will be better if added with compost and AMF both singly and interactively. In silica sand post-mining, the addition of MycoSilvi and ameliorant soil (32.5 $\mathrm{g}$ of compost and 7.2 $\mathrm{g}$ of lime) increased the growth of F. moluccana, S. saman, dan $C$. siamea with a percent increase in height seedlings by $173.19 \%$, $233.71 \%, 257.56 \%$, diameter of $186.79 \%$, $303.48 \%$, 562.08\%, and biomass by $995.93 \%, 667.86 \%$, $1447.62 \%$ (Jayani et al., 2018). In lime post-mining soils, a single AMF produces height, diameter, and biomass of Alstonia scholaris, Acacia auriculiformis, and Mutingia calabura seedlings better than without AMF, and compost singly produced the best biomass of $P$. falcataria seedlings up to a $23.16 \%$ increase from control (Prayudyaningsih, 2014; 
Wasis \& Sa'diah 2019). AMF significantly increased the biomass of $L$. leucocephala which was better than without AMF in masand (crushed basalt) (Habte \& Antal, 2010). L. leucocephala seedlings that were inoculated with AMF (Gigaspora margarita, Glomus deserticola, and $G$. etunicatum) also significantly produced better biomass compared to control seedlings in sandy loam media (Dixon et al., 1993). Rani et al. (2019) also stated that a mixture of soil, vermicompost, and AMF (Acaulospora scrobiculata $+G$. intraradices) also were able to produce the best biomass for L. leucocephala seedlings.

Effect of AMF and soil ameliorant on nutrient uptake of $\boldsymbol{L}$. leucocephala seedlings Nutrient uptake is influenced by the addition of organic matter and AMF inoculation (Biswas et al., 2000; Shao et al., 2018). The results showed that the addition of AMF and soil ameliorant had a significant effect on nutrient uptake of L. leucocephala seedlings (Table 2). Interaction of compost $7.5 \%$ and MycoSilvi produce the best nutrient uptake of $L$. leucocephala seedlings of $17.64 \mathrm{~g} \mathrm{plant}^{-1}$ $(\mathrm{N}), 2.42 \mathrm{~g} \mathrm{plant}^{-1}(\mathrm{P})$, and $18.05 \mathrm{~g} \mathrm{plant}^{-1}(\mathrm{~K})$, while the nutrient uptake control seedlings produced were only $0.82 \mathrm{~g}$ $\operatorname{plant}^{-1}(\mathrm{~N}), 0.14 \mathrm{~g} \mathrm{plant}^{-1}(\mathrm{P})$, and $0.49 \mathrm{~g} \mathrm{plant}^{-1}(\mathrm{~K})$. Base on these conditions, it can be assumed that the addition of $7.5 \%$ compost and MycoSilvi can provide optimal nutrient uptake for L. leucocephala seedlings in limestone post-mining soils. Bustami et al. (2012) stated that plant growth will reach optimum if growth-supporting factors such as macronutrients $\mathrm{N}, \mathrm{P}$, and $\mathrm{K}$ are in optimum condition and available to plants. Compost undergoes a decomposition process which then releases $\mathrm{N}, \mathrm{P}$, and $\mathrm{K}$, thereby increasing the availability of nutrients for plants (Hasanudin, 2003; Rani et al., 2019).
Mycosilvi contains AMF which can absorb $\mathrm{N}$ and $\mathrm{Mg}$ nutrients as the compiler of chlorophyll. (Jayani et al., 2018). FMA also helps absorb $\mathrm{P}$ nutrients which are useful in stimulating root growth especially in young plants and increasing plant resistance when nutrient deficiency and dryness such as in limestone post-mining soil (Manaroinsong \& Lolong, 2015; Chairul et al., 2019). The results of the study (He et al., 2017) also mentioned that AMF inoculation had a significant influence on $\mathrm{N}$ and $\mathrm{P}$ nutrient uptake in limestone soils. Root morphological conditions such as thickness, length, and the number of roots affect optimal nutrient uptake (Biswas et al., 2000). The better the root development, then the better the nutrient uptake that seedlings (Ginting et al., 2018a).

Correlation of root colonization, nutrient uptake, and biomass of $L$. leucocephala seedlings Root colonization has a positive correlation ( $\mathrm{r}$ ) to nutrient uptake of $\mathrm{N}, \mathrm{P}$, and $\mathrm{K}$ (Figure 1). The correlation magnitude of root colonization and nutrient uptake of N (Figure 1a), P (Figure 1b), and K (Figure 1c) respectively were $0.273\left(\mathrm{R}^{2}=0.079\right), 0.314\left(\mathrm{R}^{2}=\right.$ $0.103)$, and $0.209\left(\mathrm{R}^{2}=0.044\right)$. These positive correlations indicate that an increase in percent colonization of roots influences on increasing nutrient uptake of $\mathrm{N}, \mathrm{P}$, and $\mathrm{K}$ seedlings of L. leucocephala. MycoSilvi contains FMA which has external hyphae so that it helps in expanding nutrient uptake for plants (Jayani et al., 2018). At roots inoculated with AMF, nutrients available in the soil will be more easily absorbed compared to without AMF inoculation (Ginting et al., 2018b).

The availability of these nutrients is followed by an increase in photosynthetic activity which supports in
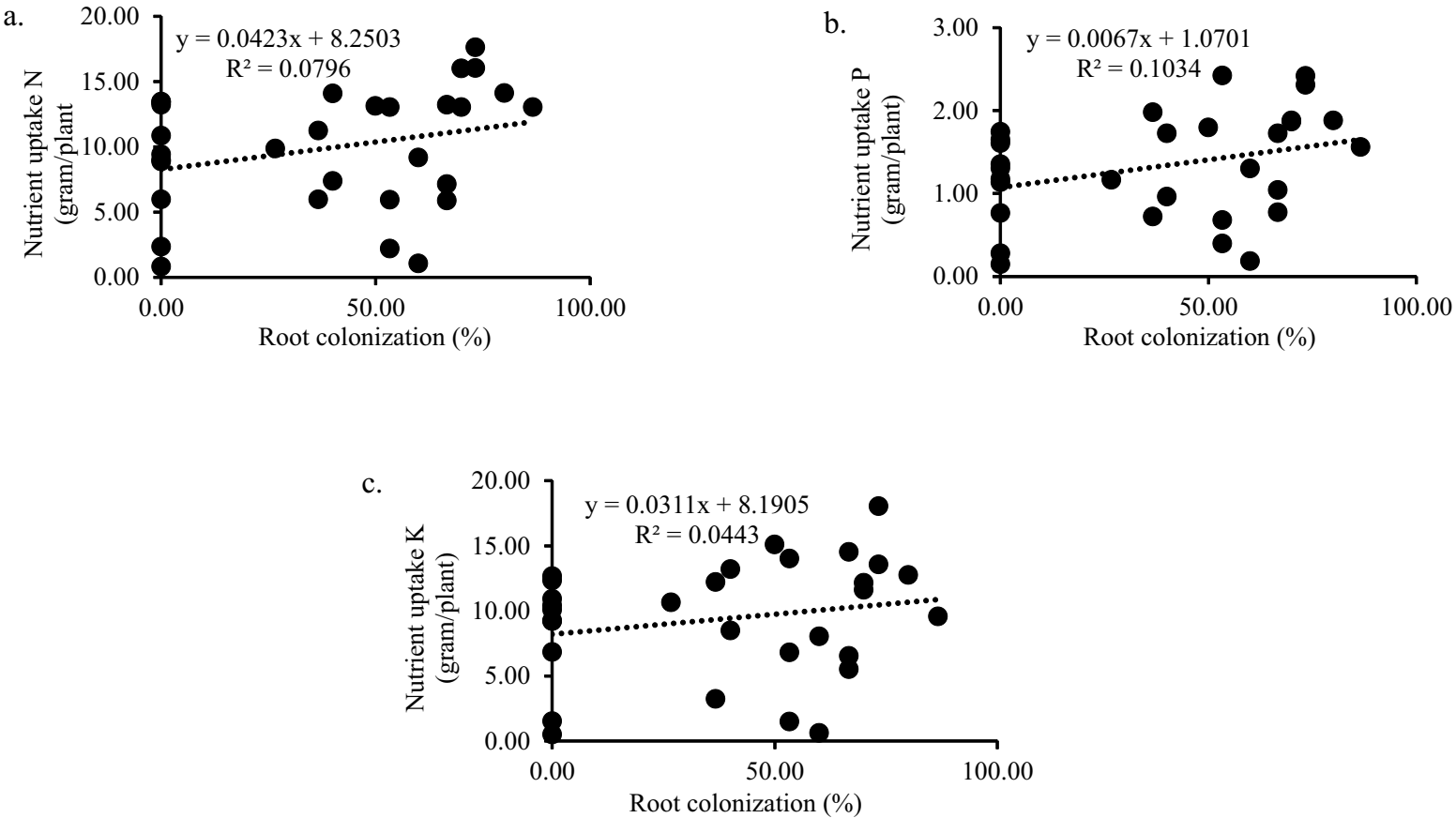

Figure 1 Correlation of root colonization and nutrient uptake of $L$. leucocephala seedlings. 

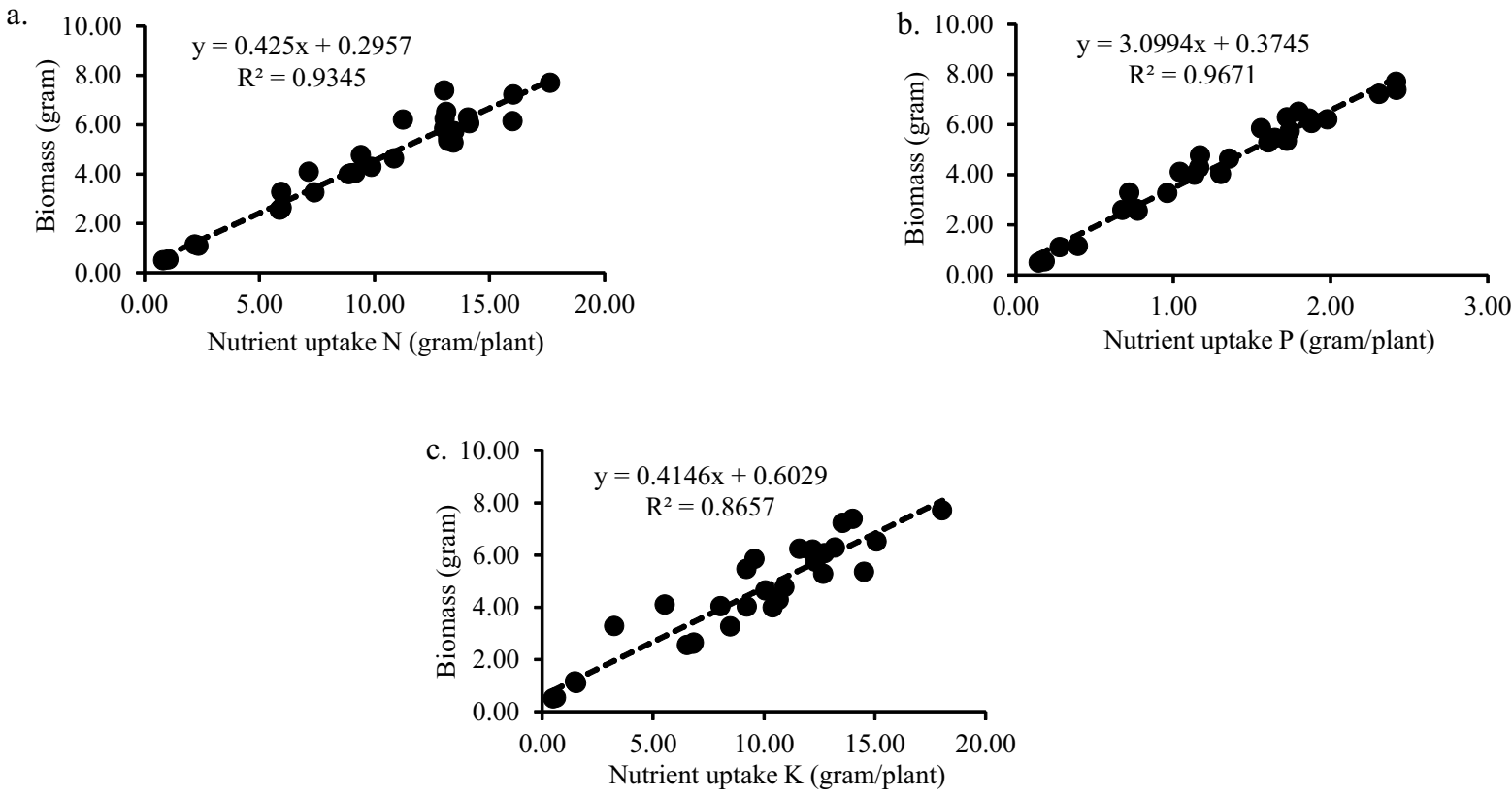

Figure 2 Correlation between nutrient uptake and biomass L. leucocephala seedling.

increasing plant biomass (Putri et al., 2016). AMF can significantly help plants absorb nutrients thereby increasing biomass in plants (Bonfante \& Genre 2010). The results showed that nutrient uptake had a positive (r) correlation to L. leucocephala seedlings biomass (Figure 2). The correlation magnitude of nutrient uptake of $\mathrm{N}$ (Figure 2a), $\mathrm{P}$ (Figure 2b), and $\mathrm{K}$ (Figure 2c) to seedlings biomass respectively were $0.951\left(R^{2}=0.934\right), 0.964\left(R^{2}=0.967\right)$, and $0.911\left(\mathrm{R}^{2}=0.865\right)$. This shows that there is a very high correlation between plant nutrient uptake and L.leucocephala seedlings biomass. The amount of N, P, and $\mathrm{K}$ nutrients absorbed by plants has a close relationship with the biomass produced, the higher the nutrient uptake, the higher the biomass produced (Putri et al., 2016; Sumarni et al., 2016).

\section{Conclusion}

Arbuscular mycorrhizal fungi and soil ameliorant play an essential aspect in increasing the growth of L.leucocephala seedlings in limestone post-mining soils. The interaction of compost dose of $7.5 \%$ and MycoSilvi capable to produce the best growth response to height, diameter, biomass, and seedlings nutrient uptake compared to other treatments. There is a positive correlation between root infection and N, $\mathrm{P}$, and $\mathrm{K}$ nutrient uptake of $0.273,0.314$, and 0.209 . Nutrient uptake of $\mathrm{N}, \mathrm{P}$, and $\mathrm{K}$ to biomass also has a positive correlation that is equal to $0.951,0.964$, and 0.911 .

\section{Acknowledgement}

The author thanks to Directorate of Research and Community Service, Directorate General of Research Strengthening and Development, Ministry of Research, Technology, and Higher Education, the Republic of Indonesia for funding research through the postgraduate thesis grant scheme No. 3/E1/KP.PTNBH/2019 dated March $29,2019$.

\section{References}

Afra, D., Makalew, N., Damayanti, V. D., \& Hadi, A. A. (2008). Rencana penataan lanskap Gunung Kapur Cibadak untuk ekowisata di Kecamatan Ciampea Kabupaten Bogor. Jurnal Ilmu Pertanian Indonesia, 13(3), 182-193.

Aminah, S., Soedarsono, G. B., \& Sastro, Y. (2003). Teknologi pengomposan. Jakarta: Balai Pengkajian Teknologi Pertanian.

Aprillia, D. A., Riniarti, M., \& Bintoro, A. (2019). The application of ectomycoriza in ex-limestone mining growth media to assist the growth of mangium (Acacia mangium). Jurnal Sylva Lestari, 7(3), 332-341. https://doi.org/10.23960/js137332-341

Ardakani, M. R., Mazaheri, D., Mafakheri, S., \& Moghaddam, A. (2011). Absorption efficiency of N, P, K through triple inoculation of wheat (Triticum aestivum L.) by Azospirillum brasilense, Streptomyces sp., Glomus intraradices and manure application. Physiology and Molecular Biology of Plants, 17(2), 181-192. https://doi.org/10.1007/s12298-011-0065-7

Atawodi, S. E., Mari, D., Atawodi, J. C., \& Yahaya, Y. (2008). Assessment of Leucaena leucocephala leaves as feed supplement in laying hens. African Journal of Biotechnology, 7(3), 317-321.

Aziz, M. (2010). Batu kapur dan peningkatan nilai tambah serta spesifikasi untuk industri. Jurnal Teknologi 
Mineral dan Batubara, 3(6), 116-131. https://doi.org/ 10.30556/jtmb.Vol6.No3.2010.857

Biswas, J. C., Ladha, J. K., \& Dazzo, F. B. (2000). Rhizobia inoculation improves nutrient uptake and growth of lowland rice. Soil Science Society of America Journal, 64(5), 1644-1650. https://doi.org/10.2136/sssaj2000. $6451644 x$

Bonfante, P. \& Genre, A. (2010). Mechanisms underlying beneficial plant-fungus interactions in mycorrhizal symbiosis. Nature Communications, 1(4), 1-11. https://doi.org/10.1038/ncomms 1046

Brandon, N. J., Shelton, H. M., \& Peck, D. M. (1997). Factors affecting the early growth of Leucaena leucocephala. Australian Journal of Experimental Agriculture, 37(1), 35-43. https://doi.org/10.1071/EA96009

Budi, S. W., Wibowo, C., Sukendro, A., \& Bekti, H. S. (2020). Growth improvement of Falcataria moluccana inoculated with MycoSilvi grown in post mining silica sand soil medium amended with soil ameliorants. Biodiversitas, 21(1), 421-427. https://doi.org/10.13057/ biodiv/d210149

Bustami, Sufardi, \& Bakhtiar. (2012). Serapan hara dan efisiensi phopfat serta pertumbuhan padi varietas lokal. Jurnal Manajemen Sumber Daya Lahan, 1(2), 159-170.

Cahyadi, A. (2010). Pengelolaan Kawasan Karst dan Peranannya dalam Siklus Karbon di Indonesia. Paper presented at Seminar Nasional Perubahan Iklim di Indonesia (pp. 1-14). Yogyakarta, Indonesia.

Cakyayanti, I. D., Setiadi, Y. (2014). Evaluasi hasil-hasil penelitian berbagai jenis pohon dalam rangka rehabilitasi lahan tambang mineral di Indonesia (kajian pustaka). Jurnal Silvikultur Tropika, 5(2), 91-96.

Cavagnaro, T. R., Smith, F. A., Ayling, S. M., \& Smith, S. E. (2003). Growth and phosphorus nutrition of a Paris-type arbuscular mycorrhizal symbiosis. New Phytologist, 157(1), 127-134. https://doi.org/10.1046/j.14698137.2003.00654.x

Chairul, Noli, Z. A., Suwirmen, Syamsuardi, \& Reini. (2019). Research article exploration of indigenous arbuscular mycorrhizal fungi on post mining soil as rehabilitation strategy. Journal Biological Sciences, 19(3), 218-223. https://doi.org/10.3923/jbs.2019.218. 223

Chen, Y., Li, D., Li, D., Wu, X., \& Zheng, Y. (2011). Assessment for soil improvement benefit of land rehabilitation in dump areas. Mathematical and Computer Modelling, 54(3-4), 1204-1212. https://doi. org/10.1016/j.mcm.2010.11.054

Clapp, J. P., Fitter, A. H., \& Merryweather, J. W. (1996). Methods for the examination of organismal diversity in soils and sediments. (G. S. Hall, P. Lasserre, \& D. L. Hawksworth, Eds.). Wallingford, Oxon: CAB International.

Dharmaputri, N., Wijaya, I., \& Adiartayasa, W. (2016). Identifikasi mikoriza vesikular arbuskular pada rhizosfer tanaman lamtoro (Leucaena leucocephala) dan kaliandra (Calliandra calothyrsus) serta perbanyakannya dengan media zeolit. Journal of Tropical Agroecotechnology, 5(2), 171-180.

Dixon, R. K., Rao, M.V., \& Garg, V. K. (1993). Water relations and gas exchange of mycorrhizal Leucaena leucocephala seedlings. Journal of Tropical Forest Science, 6(4), 542-552.

Djamhari, S. (2010). Perairan sebagai lahan bantu dalam pengembangan. Hidrosfir Indonesia, 5(3), 1-11.

Ginting, E. N., Rahutomo, S. R., \& Sutarta, E. S. (2018a). Efisiensi serapan hara beberapa jenis pupuk pada bibit kelapa sawit. Jurnal Penelitian Kelapa Sawit, 26(2), 79-90.https://doi.org/10.22302/iopri.jur.jpks.v26i2.38

Ginting, I. F., Yusnaini, S, Dermiati, Rini. M. V. (2018b). Pengaruh inokulasi fungi mikoriza arbuskula dan penambahan bahan organik pada tanah pasca penambangan galian $\mathrm{C}$ terhadap pertumbuhan dan serapan hara $\mathrm{P}$ tanaman jagung (Zea mays L.). Jurnal Agrotek Tropoika, 6(2), 110-118.

Habte, M., \& Antal, M. J. (2010). Reaction of mycorrhizal and nonmycorrhizal leucaena leucocephala to charcoal amendment of mansand and soil. Communications in Soil Science and Plant Analysis, 41, 540-552. https://doi.org/ 10.1080/00103620903527936

Hakim, L. (2011). Ekosistem 13 gua dan sumber air Ciampea terancam punah. Lembaga Ilmu Pengetahuan Indonesia. Retrieved from http://lipi.go.id/berita/ ekosistem-13-gua-dan-sumber-air-ciampea-terancampunah $/ 6188$

Hasanudin. (2003). Peningkatan ketersediaan dan serapan N dan $\mathrm{P}$ serta hasil tanaman jagung melalui inokulasi mikoriza, azotobakter dan bahan organik pada ultisol. Jurnal Ilmu-Ilmu Pertanian Indonesia, 5(2), 83-89.

He, Y., Jiang, C, Yang, H., Wang, Y., \& Zhong Z. (2017). Arbuscular mycorrhizal fungal composition affects the growth and nutrient acquisition of two plants from a karst area. Sains Malaysiana, 46(10), 1701-1708. https://doi.org/10.17576/jsm-2017-4610-05

Hendrati, R. L., \& Hidayati, N. (2018). Sembilan populasi Leucaena leucochepala (Lam.) de Wit. asal indonesia untuk pemuliaan kayu energi versus var. tarramba. Jurnal Perbenihan Tanaman Hutan, 6(1), 15-30.

Jayani, F. M., Budi, S. W., \& Pamoengkas, P. (2018). Response of forest tree species inoculated with MycoSilvi and soil ameliorant addition grown in silica 
sand. Asian Journal of Agriculture and Biology, 6(4), 556-565.

Manaroinsong, E., \& Lolong, A. A. (2015). Identifikasi cendawan mikoriza arbuskular (CMA) pada beberapa tekstur tanah di lahan kelapa sawit di Kalimantan Tengah. Buletin Palma, 16(2), 203-210. https://doi.org/ 10.21082/bp.v16n2.2015.203-210

Mansur, I. (2013). Teknik silvikultur untuk reklamasi lahan bekas tambang. Bogor: SEAMEO BIOTROP.

Nusantara, A. D., Bertham, Y. H., \&Mansur, I. (2012). Bekerja dengan fungi mikoriza arbuskula. Bogor: SEAMEO BIOTROP

Pramitasari, H. E., Wardiyati, T., Nawawi, M. (2016). Pengaruh dosis pupuk nitrogen dan tingkat kepadatan tanaman terhadap pertumbuhan dan hasil tanaman kailan (Brassica oleraceae L.). Produksi Tanaman, 4(1), 49-56. https://doi.org/10.32938/sc.v1i01.2

Prayudyaningsih, R. (2014). Pertumbuhan semai Alstonia scholaris, Acacia auriculiformis dan Muntingia calabura yang diinokulasi fungi mikoriza arbuskula pada media tanah bekas tambang kapur. Jurnal Penelitian Kehutanan Wallacea, 3(1), 13. https://doi.org/ 10.18330/jwallacea.2014.vol3iss 1pp13-23

Prayudyaningsih, R., \& Sari, R. (2016). Aplikasi fungi mikoriza arbuskula (FMA) dan kompos untuk meningkatkan pertumbuhan semai jati (Tectona grandis Linn.F) pada media tanah bekas tambang kapur. Jurnal Penelitian Kehutanan Wallacea, 5(1), 37-46. https://doi. org/10.18330/jwallacea.2016.vol5iss1pp37-46

Prayudyaningsih, R., Faridah, E., Sumardi, \& Sunarminto B. H. (2015). Dampak fasilitasi tumbuhan legum penutup tanah dan tanaman bermikoriza pada suksesi primer di lahan bekas tambang kapur. Jurnal Manusia dan Lingkungan, 2(3), 310-315. https://doi.org/10.22146/ jml.18756

Purwanti, B., Budi, S. W., \& Wasis, B. (2019). Status fungi mikoriza arbuskula (FMA) pada rizosfer jernang (Daemonorops Draco Blume) di Jambi. Media Konservasi, 24(3), 261-268. https://doi.org/10.29244/ medkon.24.3.261-268

Puthur, J. T., Prasad, K. V. S. K., Sharmila, P., \& Saradhi, P. P. (1998). Vesicular arbuscular mycorrhizal fungi improves establishment of micropropagated Leucaena leucocephala plantlets. Plant Cell, Tissue and Organ Culture, 53, 41-47. https://doi.org/10.1023/A:10060680 26377

Putri, K. D., Sampoerno, \& Puspita, F. (2016). Pemberian beberapa konsentrasi bio-urin sapi pada bibit tanaman gaharu (Aquilaria malaccensis). Jurnal Online Mahasiswa Faperta, 3, 1-9.

Rahmadi, C. (2017). Ekosistem kawasan karst tak tergantikan. Lembaga Ilmu Pengetahuan Indonesia. Retrieved from http://lipi.go.id/lipimedia/ekosistemkawasan-karst-tak\%20\%09tergantikan/18002

Rahmayanti, A. Y., Rini, M. V., Arif, M. A. S., \& Yusnaini, S. (2013). Pengaruh pemberian fungi mikoriza arbuskular dan kompos kulit buah kakao pada pertumbuhan bibit kakao (Theobroma cacao L.). Jurnal Agrotek Tropika, 1(2), 121-127.

Rani, A., Kumar, N., Ram, A., Dev, I., \& Uthappa, A. R. (2019). Effect of growing media and arbuscular mycorrhiza fungi on seedling growth of Leucaena leucocephala (Lam.) de Wit. Indian Journal of Agroforestry, 21(2), 22-28.

Rosita, I., Budi, S. W., \& Wulandari, S. (2017). Efektivitas fungi mikoriza arbuskula dan pupuk $\mathrm{P}$ terhadap pertumbuhan bibit leda (Eucalyptus Deglupta Blume) di media tanah pasca tambang. Jurnal Silvikultur Tropika, 8(2), 96-102.

Setyorini, D., Saraswati, R., \& Anwar, E. K. (2006). Pupuk organik dan pupuk hayati. (R. D. M. Simanungkalit, D. A. Suriadikarta, R. Saraswati, D. Setyorini, W. Hartatik, Eds.). Bogor: Balai Besar Penelitian dan Pengembangan Sumberdaya Lahan Pertanian.

Shao, Y. D., Zhang, D. J., Hu, X. C., Wu, Q. S., Jiang, C. J., Xia, T. J., ..., \& Kuča, K. (2018). Mycorrhiza-induced changes in root growth and nutrient absorption of tea plants. Plant Soil and Environment, 64(6), 283-289. https://doi.org/10.17221/126/2018-PSE

Siregar, P., Fauzi, \& Supriadi. (2017). Pengaruh pemberian beberapa sumber bahan organik dan masa inkubasi terhadap beberapa aspek kimia kesuburan tanah ultisol. Jurnal Agroteknologi, 5(2), 256-264.

Smith, S. E. \& Read, D. J. (2010). Mycorrhizal symbiosis. New York: Academic Press.

Suita, E. (2019). Breaking dormancy and testing method in determining seed viability of lamtoro (Leucaena leucocephala lam. De wit. Journal of Plantation Forest Research, 16(2), 59-72. https://doi.org/10.20886/jpht. 2019.16.2.59-72

Sumarni, N., Rosliani, R., \& Basuki, R. S. (2016). Respons pertumbuhan, hasil umbi, dan serapan hara NPK tanaman bawang merah terhadap berbagai dosis pemupukan NPK pada tanah alluvial. Jurnal Hortikultura, 22(4), 366. https://doi.org/10.21082/jhort.v22n4.2012.p366-375

Surya, Nuraini, \& Widianto. (2017). Kajian porositas tanah pada pemberian beberapa jenis bahan organik di perkebunan kopi robusta. Jurnal Tanah dan Sumber Daya Lahan, 4(1), 463-471.

Wasis, B., Ghaida, S. H., \& Winata, B. (2019). Application of coconut shell charcoal and NPK fertilizer toward Acacia mangium growth on the soil of ex-limestone mining in 
Bogor, Indonesia. Agriculture and Environmental Science, 4(1), 75-82. https://doi.org/10.26832/245 66632.2019.0401012

Wasis, B., \& Sa'idah H. (2019). Pertumbuhan semai sengon (Paraserianthes Falcataria (L.) Nielsen) pada media tanah bekas tambang kapur dengan penambahan pupuk kompos dan NPK. Jurnal Silvikultur Tropika, 10(1), 51-57.

Widiastuti, H., Sukarno, N., Darusman, L. K., Goenadi, D. H., Smith, S., Guhardja, E., ..., \& Perkebunan, B. (2003). Aktivitas fosfatase dan produksi asam organik di rhizosfer dan hifosfer bibit kelapa sawit bermikoriza.
Menara Perkebunan. 71(2), 70-81. https://doi.org/10. 22302/iribb.jur.mp.v71i2.164

Wolfe, B. T., \& van Bloem, S. J. (2012). Subtropical dry forest regeneration in grass-invaded areas of Puerto Rico: Understanding why Leucaena leucocephala dominates and native species fail. Forest Ecology and Management, 267, 253-261. https://doi.org/10.1016/ j.foreco.2011.12. 015

Yulnafatmawita, Maira, L., Junaidi, Yusmini, \& Hakim, N. (2005). Peranan bahan organik dalam pembebasan Pterikat pada tanah andisol. Jurnal Solum, 2(2), 69-73. 